\title{
Pyle's Sweet, Thin, Clear Tune: The Garden Behind the Moon
}

Hans Krout had a fiddle, and he could play you a tune so sweet and thin and clear that it would make your throat fill up with happiness to listen to him.

At about the same time that England's Tennyson and the Rossettis were indulging in moony-eyed nostalgia for a Middle Ages that vacillated between brooding opera and creamy romance, the American Howard Pyle was writing about, and illustrating, a Middle Ages of his own invention, a sort of fourteenth century YMCA picnic where good children could safely dream, drowsed with the fumes of Lysol. Shortly after Pyle's death, Henry Mills Alden wrote in Harper's that Pyle's work was "a fresh revival of the romantic. But, though it occupied the field of wonder, it had no Rossetti-like transfiguration and exaltation, no vagueness. Without any loss of wonder, his meanings were plain." Robert Lawson enthusiastically confirms the freshness of Pyle's Europe:

Here were castles, not moss-hung but lived-in, spacious, clean, .... . Here were towers, not buried in ivy and watery moonlight, but soaring

breathlessly into clear and sparkling

skies . . . no dreary weeping willows

these, nor moss-hung churchyard relics.

These trees were vigorous, alive . . .

No wonder that this land and these people of Howard Pyle's seemed like a childhood vision of the Promised Land come true. ${ }^{2}$

Pyle did not actually visit Europe until many years after he'd written numerous books about the European past; he did indeed invent a medieval Europe that was peculiarly nineteenth century, and peculiarly American-and the stories he told of the exuberant, muscular men with the tastes and interests of ten-year-old boys who inhabited it made it peculiarly charming.

In the midst of all this brightly lit and wonderfully energetic adventure, one book stands out. Pyle's Garden Behind the Moon seems to be as dreamy, as vague, and as mystical as Men of Iron and The Merry Adventures of Robin Hood are plain and practical-as "sweet and thin and clear" as Pyle's other books are loud and boisterous.

Pyle's young son died while he was on a trip to Jamaica, before The Garden Behind the Moon was written; Pyle dedicated the book "to the Little Boy in the Moon Garden," and as the book suggests, the Moon Garden is the heavenly dwelling of those who die young. Perhaps that explains why The Garden Behind the Moon is so different from Pyle's other works, which hardly ever penetrate the clean surface of the delightfully unsubtle world they describe; The Garden struggles seriously with hard and highly emotional issues, ideas of death and salvation that might well come to be important to a grieving father.

Not surprisingly, those who dislike Pyle's work admire the sweet, thin, clear tune of The Garden Behind the Moon. John Rowe Townsend, who seriously misses the point when he dismisses Pyle's majestically inventive pseudo-archaisms for being untrue to the real Medieval facts, says, "To my mind, his writing is at its best in his fantasy The Garden Behind the Moon . . . , a sad and often moving allegory which is strongly reminiscent of George MacDonald." Also not surprising, given its difference from the rest of Pyle's work, is the neglect of The Garden; the book has been out of print for many decades.

.. Pyle was writing about, and illustrating a Middle Ages of his own invention, a sort of fourteenth century YMCA picnic...

It doesn't deserve to be neglected. Despite those reminiscences of George MacDonald - and they are obvious reminiscences-nobody but Howard Pyle could have written The Garden Behind the Moon. Townsend says the book "does not have MacDonald's imaginative force;" he's right: it doesn't. It has Pyle's imaginative force. It is a pecularly Pylean version of MacDonald-land-the sort of mystical fantasy only a proclaimed Swedenborgian who had been born a common-sense Quaker could write.

George MacDoriald's fantasies stand somewhere near the start of the line of stories that led eventually to Tolkien's tales of Middle-earth and C.S. Lewis's Narniastories that combine the matter of fairy tales with the content of Christianity. In such stories, creatures and events that once served stranger gods come to represent Christian virtues and problems, but as Leslie Fiedler suggests, "the implicit values as well as the explicit mythology of the fairy tale remain outside Christianity." 4 In fantasies like The Golden Key, MacDonald's characters reach presumably Christian conclusions by means of strange voyages through unsettling fairy-talish lands; in doing so, they evoke a profound disturbance that's larger than the spiritual themes they are supposed to evoke, and that are supposed to encompass them. The character Tangle in The Golden Key makes the problem brutally clear: "she had a marvelous sense that she was in the secret of the earth and all its ways . . . she understood it all, and saw that everything meant the same thing, though she could not have put it into words again." "The matter of fairy tales is always too strange to be explained; in fairy tales, almost anything can be understood to actually mean something else. That's why fairy tales themselves have been explained so differently by so many different commentators, and why MacDonald's wonderful stories are so wonderfully vague yet so apparently meaningful.

Pyle's Garden Behind the Moon has the same vagueness and the same apparent profundity In it, Pyle tells us that Hans Krout, the addled shoemaker, "knew all about the Moon-Angel and the moon-path and the moon-garden and the moonhouse;"' Pyle's young hero David appreciates these things because he is himself a "moon-calf." The first half of the book tells how David takes the moonpath to the moon, meets the man in the moon, and visits the moon-house and the moon-garden, all with the help of the Moon-Angel. If Pyle didn't want the moon to be a symbol here, I suspect he was going about it the wrong way.

But on first reading, the meaning of it all isn't particularly clear; it seems to be a mixture of high spirits and high madnesspart moonshine, part lunacy. Take, for instance, this passage:

And as it was with David, so it is with everyone: as soon as you find the back stairs of the moon-house, you lose sight of the front stairs, and there is no other way out of the second story; and when you find the front stairs, you may hunt until your head spins, but not so much as a single step of the back stairs can you find (pp. 72-3)

This may mean that the only way to get to heaven from earth is to die, and the only way to get to earth from heaven is to be born; then again, it may not mean that at all.

But a closer look shows that there is method in Pyle's moon-madness.

Throughout The Garden Behind the Moon, Pyle refers to the earth as "brown," the moon as "pale" or "pure." David, the moon-calf, has a "pale" face, and "pale blue" eyes, while the other children of his native village have "brown freckled faces and shock heads and strong hands that were nearly always dirty" (p. 11). They 
sound like the sort of boisterous, ordinary children that might hang around one of Pyle's bustling, ordinary medieval castles; and they call David a moon-calf because they consider him a simpleton. But for Pyle, David's simplicity is actually a wisdom beyond ordinary knowledge; Pyle speaks disdainfully of "a world-wise scientist with two pair of short-sighted spectacles on his nose" (p. 9), and makes it clear that world-wisdom, being merely of this world, sees less than moon-wisdom. "Well, well," he says of his own fantasy, "maybe it is all nonsense, but sometimes there is more solid truth in nonsense than in a whole peck of potatoes" (p. 59).

In fact, because it is beyond earthly reason, moon-logic is something like imagination; Pyle tells us that "David was of that kind who can see more through the square hole of a millstone than the other side of it" (p. 34). It is also something like faith, for Pyle borrows from MacDonald the intertwining of imaginative impossibilities and spiritual ideals. David cannot walk on the moon-path until he believes that walking on the path of light the moon casts over water is possible; and when he does walk on it, part of him remains behind: "part of you here, part of you there. That's the way to travel the moon-path" (p. 23). The part of him left behind is his physical body, for the moonpath takes one from the merely physical brown earth and all that belongs to it.

But as those who continue to exist on earth understand it, to be not of this earth is to be dead. So the moon represents not just imagination beyond earthly limitations and faith beyond reason, but also, death beyond earthly life. The Moon-Angel is the angel of death; Pyle tells his readers that the song the Moon-Angel sings is "such as you will never hear until the clay stoppers are taken out of your ears" ( $p$. 68 ). Because earthly reason suggests that death is extinction, "to most people the Moon-Angel appears terrible. For there are few folk, unless it is a moon-calf like David, who can see him in his true shape" (p. 35). Furthermore, some people are dreadfully afraid of the moon-house; it seems to them white and cold and awful" (p. 44).

At one point in The Garden Behind the Moon, Pyle recalls a cobbler out of his own childhood, who "had a little black dog, blind of both eyes, whom the Moon-Angel used to lead around hither and thither with a string that nobody could see" ( $p$. 16). That invisible string sums up all the actually undreadful things that Pyle wants moonishness to stand for. Whether it be faith beyond reason, imagination beyond common sense, or everlasting life beyond apparent death, the moon's meanings all have to do with transcending appearances, with what is "inside" or "within" or

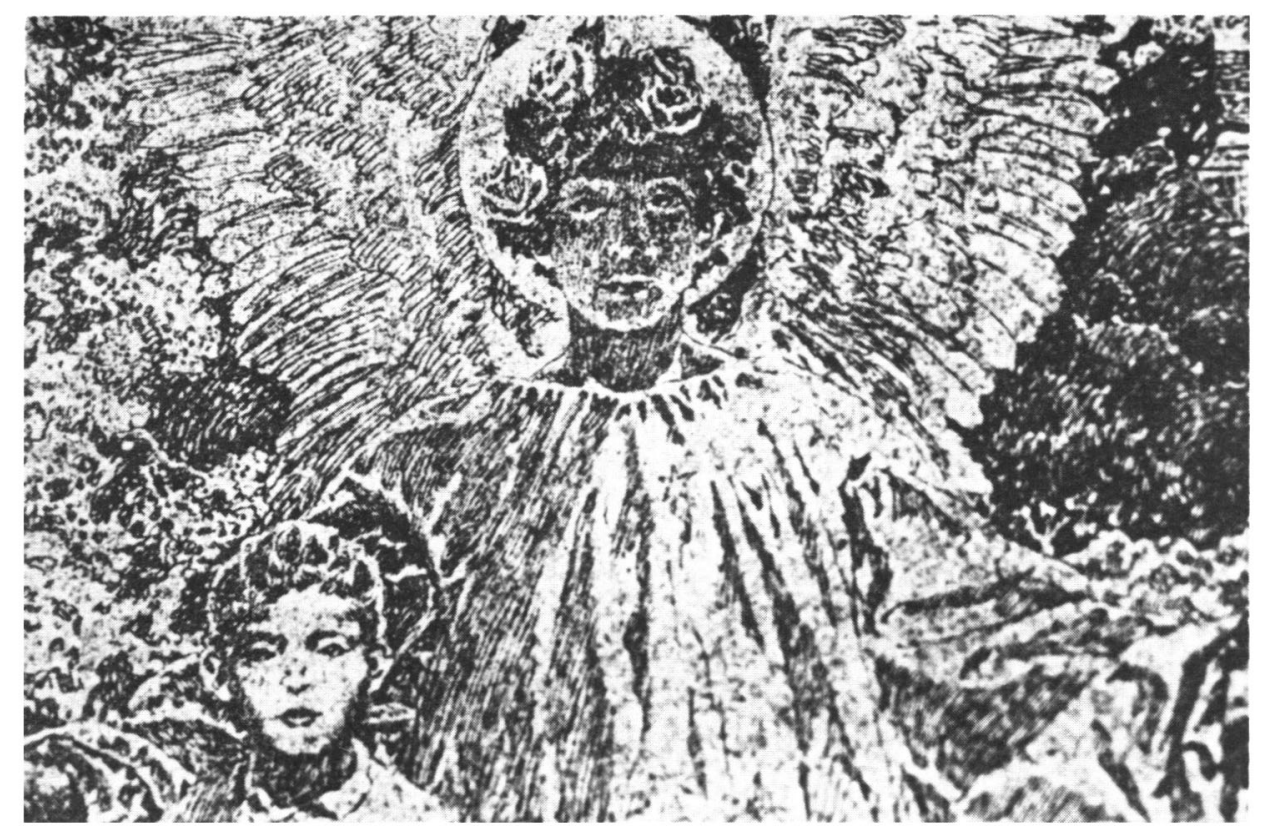

The Garden Behind the Moon

Written and illustrated by Howard Pyle.

Charles Scribner's Son

(C) 1931

"behind" things as they appear to be. Such appearances are "no more to the inside of things than the shell of the egg is to the meat" (p. 55), and "the more sad the outside, the more beautiful almost always is the inside" ( $p .56$ ). When David sees through the windows of the moon-house scenes of secret moonish assistance for those who appear, from the "outside," to be suffering on earth, he is told that he sees "the-inside-of-nothing-at-all" (p. 48)what is actually behind nothingness. Pyle himself talks about how, ever since he saw "behind" the Moon-Angel, "all I know is that ever since then I have seen things turned topsy-turvy, and men walk on their heads instead of their heels, and trees grow upside-down, and that I hear wise men talk nonsense" (p. 105). But even so, David "knew more in his little finger about the Moon-Angel and what was behind him than I shall ever be able to learn with my whole body-at least until I have cracked through the crust of things and got back into the land of right-side up again" (p. 105). Within the moon-logic of The Garden Behind the Moon, all that one might desire-the paradises of fantasy, the joys of eternal life, the support of divine concern-all is mere truth; while all that one's clay-stopped vision "knows" to be true and limited and ugly is merely a deceptive crust, a brown lie.

Since it seems to have been the death of his young child that made Pyle want so desperately to believe in this topsy-turvy world, the garden he lets his young hero find behind the moon is a paradise for children-a peculiarly Victorian paradise, but paradise nevertheless. The moongarden is "the best place out of the world in which to play" (p. 71). It is filled with happy, accepting, clean, children; it is attached to a large country estate where the linens in the children's dorm are fresh every day, and it is supervised by a beautiful lady with "a soft, gentle face" and "gentle blue eyes," who "laid her hand very gently" on David (pp. 78-9). When David later hears of the garden in which Adam and Eve lived, he is told, surprisingly, that "it was the moon-garden, too" (p. 119); it seems that was before some benevolent captain of industry bought the property and ran up the dormitories.

If The Garden Behind the Moon ended at this point, it would have been merely another sentimental fantasy of the sort the Victorians on both sides of the Atlantic churned out by the hundreds. But it doesn't end at this point. What follows makes it unique.

As David steps behind the MoonAngel, "it was as though everything had suddenly changed; as though even theythe moon and the garden-had changed to a dream in which there was something of terror and darkness" (p. 107). There is more than a little of both in the pages that follow; Pyle gets inside of the mere cozy wish-fulfillment of the first half of the book.

David grows up. He becomes too old for the innocent faith and cozy security of the moon-garden. Now he must find and express his faith in what is behind by means more suitable to maturity than 
gentle teachers and pleasant gardens. So Pyle takes David on a heroic quest, in which he must regain by harsh struggle what had come so easily before.

This sudden transition echoes a similar one in Pyle's Men of Iron. The first part of that book describes how the medieval youth Myles Fallworth democratically refuses to act as a servant to the older squires; in defeating the theoretically stronger and stubbornly undemocratic Blunt, Myles tests out the heroic qualities he will need in his later life as a fullfledged knight. Then, Pyle says,

There are now and then times in the life of every one when new and strange things occur with such rapidity that one has hardly time to catch one's breath between the happenings. It is as though the old were crumbling away-breaking in pieces-to give place to the new that is soon to take its place.

The new that takes its place is the same story we have heard already, but now retold on a larger scale; mature struggle replaces youthful apprenticeship, as a fullgrown Myles regains what was rightfully his from the theoretically stronger baron.

The twice-told tale of Men of Iron implies that the struggles of boyhood are good preparation for the similar but more significant struggles of maturity. The twicetold tale of The Garden Behind the Moon implies something a little different: that adults achieve salvation by means different from and more difficult than the means by which children do. The quite different effect of the second half of The Garden is summed up by Pyle's comment that what happened to David "was all so strange, so strange that it does not fit easily into the words of A B C's, and when a body begins telling it, it breaks all into ajumble and sounds like a fairy-tale, that is not real" (p. 106). We have moved past the moony allegory of the first half of the book, and come into a territory a lot like some of Pyle's own fairy tales, albeit in a jumble; and David, no longer a moon-calf, turns into a hero as heroic and as competent as Myles Fallworth-or perhaps even more heroic, for the old woman he meets at the Iron Man's castle says to him, "You look like a hero rather than like a man" (p. 144).

Yet Pyle keeps insisting that David is still a moon-calf. Despite the fact that this new David never makes a mistake, Pyle still wants him to be the typical fairy tale weakling who eventually triumphs; as he says at the end, after David gets the girl of his dreams, "the simpleton always marries the Princess in fairy tales, and that is why they are so true that wise people and little children would rather read them than anything else" (p. 192). Pyle is clearly one of those wise people, for in the last half of The Garden, David has experiences reminiscent of all the great simpletons of the fairy tale canon, not to mention other famous weaklings. He is helped by an old woman, as are most fairy-tale heroes. He tricks a giant, like Jack. He blows a horn, like Roland of the Chanson or Joshua of the Bible. He knocks down the giant with a stone, like his namesake in the Bible. He controls a magical horse by means of the proper bridle, like the hero of "The Golden Bird," and then rides that winged creature as Bellerophon did Pegasus.

Finally, he is found out as the Princess's rightful husband by the king's messenger, much as Cinderella was. Above all, and always, he is the unassuming weakling who turns out to be stronger than his apparently more powerful enemies.

All of this reveals how odd the twicetold tale of The Garden is. The allegory of the first telling is a vision of numbing peace, and nothing happens to David but the same delightful things over and over again; in fact, it is a vision of time suspended, so that David's body grows to manhood back on the brown earth while his spirit spends a few delightful months as a child in the moon-house. But in the second telling, the focus is clearly on activity, and lots of it; it is a series of consecutive events that make up a plot, rather than a description of a place the

... the meaning of it all isn't particularly clear; it seems to be a mixture of bigh spirits and bigh madness-part moonshine, part lunacy.

essential meaning of which is its inactive changelessness.

But Pyle does not let up on the allegory. Every object and every being David meets on his quest has a meaning, and finally, the meaning ties the two parts of the book together. Even though he does it differently, David still represents the same wish-fulfillment; he is still the mooncalf who can get inside things because he is not limited by earthly values. Put more baldly, David represents a faith that Pyle wishes to believe transcends and always triumphs over worldly wisdom and worldly power.

That faith is no longer just innocence. In fact, the point of the second half of the book is that mere innocence is not enough for those who must live in a fallen world. The object of David's quest is the Wonder Box, inside of which is hidden the joy that Adam and Eve lost back in the garden. Apparently they lost it for all but children, who may, like the young David, visit that garden still. But David agrees that Adam and Eve were right to open the box, for it contained both the greatest sorrow in the world, and the greatest joy, and "surely it is worth suffering the greatest sorrow for the sake of the greatest joy" (p. 120). Pyle refocuses the meaning of the Biblical story of Adam and Eve in order to suggest that it is better to be experienced than to be innocent, better to live life as we know it to be than to lust after peaceful gardens.

Unfortunately, Adam and Eve were so terrified of the sorrow they found in the Wonder Box that they left the joy behind. David wrests it from the Iron Man. He has the mature strength to realize the joy behind consciousness of sorrow. Through suffering pain, David finds a joy greater than the unconditioned and therefore limited joy of the garden.

All of this is reasonably orthodox Christianity; Pyle makes it a powerful literary statement by telling the second story as a topsy-turvey version of the first. Action replaces repetition. The oncecomforting Moon-Angel who was more than he seemed is replaced by the Iron Man, who is less than he seems; and the beautiful lady who looks after the beautiful garden is replaced by the old lady who looks after the foreboding castle. That the castle and the garden are the same place seen from two different perspectives becomes clear when David discovers that the love of his life is being held in captivity in the castle:

"But 1 thought you were in the moongarden," cried David. "So I am," called Phyllis. "This is the moon-garden! Oh, help me away from it!"

What was a paradise of secure comfort for children in need of security and comfort has become a prison for adults in need of freedom. What was joyous for children turns out to be not nearly enough for adults, so Pyle presents his twice-told tale to describe two quite different means of salvation-that open to innocents, and that open to those no longer innocent.

There is, then, something of William Blake in The Garden Behind the Moon; and this Blake-like double perspective brilliantly justifies the book's apparent failings. Does the comfortably secure garden of the first part seem sentimental, and rather claustrophobic? Yes, of course it does, and that's why there is a second part. Does the heroic quest of the second part seem rather over-muscular, and does it ignore real emotions in favor of good fights? Of course it does, to emphasizse its difference from the first part.

The swoony sentiment of the first part represents an attitude to life quite unlike Pyle's usual muscular common sense. But even Pyle's swooning is muscular swooning-masculine, as masculinity has traditionally been understood. I find it revealing that Men of Iron, a book about a boy dedicated to revenging crimes against 
his father, should contain no scenes that reveal the love of father and son for each other; the few times Pyle puts them together he says nothing of their words and feelings, as if he were embarrassed to describe such tender emotions. In the more emotional context of The Garden Behind the Moon, Pyle seems to have given one and the same character both his wishes for his son's eternal salvation and his own personal quest, after his son's death, for the great joy he hoped he would find hidden in great sorrow. David seems to represent, first Pyle the son in a comforting heaven, then Pyle the father seeking spiritual consolation for the loss of his son; but since both are one, they can never come into contact with each other, never touch or talk. If The Garden Behind the Moon is Pyle's most personal book, if it operates as a traditional elegy offering consolation for the bereaved, then it is a surprisingly cool-headed elegy, an expression of mourning that hides far more than it reveals.

In this way more than any other, The Garden takes its place as a logical part of Pyle's work. It is as interesting, as filled with common sense and empty of vagueness, and despite its MacDonald-like mooniness, as determinedly without deep feeling, as anything Pyle wrote. As an attack on the limitations of common sense by a man filled with common sense, The Garden Behind the Moon is a fascinating and too much neglected novel.

\section{NOTES}

I"A Tribute," Howard Pyle: A Record of

His Illustrations and Writings (Detroit:

Singing Tree Press, 1969), p. vii.

2((Howard Pyle and His Times," Illustrators of Children's Books I744-1945, ed. Bertha E. Mahoney, Louise Paysom Latimer, and Beulah Folmsbee (Boston:

Horn Book, 1947), p. 110.

\section{A Milestone of Historical Fiction for Children: Otto of the Silver Hand}

\begin{abstract}
Along with Mark Twain's The Prince and the Pauper, Howard Pyle's Otto of the Silver Hand is one of the first historical novels written for children by an American. ${ }^{1}$ It is also one of the most remarkable, and it set the standard for many novels written since. There are two kinds of historical novels: those using both actual and fictional historical events and people, and those that use a historical period with fictional people and events. With the exception of Rudolph $I$ and King Ottocar of Bohemia, ${ }^{2}$ there are no actual historical people in Otto of the Silver Hand; but that Otto is more fiction than history does not lessen its significance. It has all the marks of a good historical novel: it has an exciting plot, with ample conflict and believable characters; it uses language and dialect appropriate to its setting and the characters; it has a significant, universal theme, and it presents the details of daily life in Germany of the thirteenth century accurately and unobtrusively, making the period real and alive.

The conflict between the feuding houses of Baron Conrad and Baron Henry, and the conflict between good and evil represented by the church and by the robber barons, generate the action and suspense of the novel. It focuses on the boy Otto, the innocent victim of the feud and the hope of a brighter, less cruel world, a hope nurtured by Otto's early years with the monks at St. Michaelsburg.
\end{abstract}

Steeped in the plots of traditional folktales, Howard Pyle had learned well how to construct a story that would keep readers, young or old, swiftly turning pages "to see what happens next." Pyle is especially effective in creating suspense in the episodes in which Baron Henry burns Drachenhausen, in which One-eyed Hans rescues Otto from Trutz-drachen, and in which Baron Henry cuts off Otto's hand.

The characterization of Otto also seems to be modeled on traditional folktales. Nearly all the characters are all good or all bad; only Baron Conrad and One-eyed Hans have both good and bad traits. Pyle has portrayed the problem of good and evil on a symbolic canvas, flattening most of the characters and aligning them on the side of good or evil.

One of the problems all historical novelists have is to create a reasonable facsimile of the language suitable to the time of their settings that will still be comprehensible to their readers. A writer cannot recreate the language of a specific period, certainly not that of thirteenth century Germany; but if he wants to convey the mood and flavor of a particular historical period, he cannot use completely contemporary language. On the other hand, too many "quotha's," "beset's," and "eldritch's" will destroy a period mood and flavor". Pyle seems to have struck a happy mean in Otto of the Silver Hand; the language is neither too contemporaneous
${ }^{3}$ Written for Children (Kestrel, 1974), p. 109.

4"Introduction," Beyond the Looking Glass, ed. Jonathin Cott (New York: Stonehill, and New York and London: Bowker, 1973), p. xliii.

${ }^{5}$ In Beyond the Looking Glass, p. 415.

'The Garden Behind the Moon (New York: Scribner's, 1895, rpr. 1912), p. 17.

Further references are to this edition.

As well as editing the Quarterly, Perry Nodelman worries about finding the time to finish his book about picture books, Seeing Words and Reading Pictures. 'or too archaic. The speech of his characters is somewhat formal by our standards. As Baron Conrad bids his goodbye for the last time, he says, "My little child, try not to hate thy father when thou thinkest of him hereafter, even though he be hard and bloody as thou knowest." And a little earlier, he says to One-eyed Hans, "Then take thou this child, and with the others ride with all the speed that thou canst to St. Michaelsburg. Give the child into the charge of the Abbot Otto. Tell him how that I have sworn fealty to the Emperor, and what I have gained thereby-my castle burnt, my people slain, and this poor, simple child, my only son, mutilated by the enemy."4

Ideally, themes of historical novels should reflect truths valid for both the time of the story and for the present time. The theme of Otto of the Silver Hand was as important to its time as it is for ours. When Drachenhausen is rebuilt, Otto places beneath the scutcheon over the great gate a new motto for the Vuelphs: "Better a hand of silver than a hand of iron." The novel deals majestically with the theme expressed in this last sentence. It might be reworded, "Better kindness than cruelty," though Pyle's version is more richly connotative and perhaps more reflective of the time and temper of the story.

Throughout the story, Pyle has shown the results of both cruelty and kindness, particularly by the contrasts between the 